\title{
LTF Gene
}

National Cancer Institute

\section{Source}

National Cancer Institute. LTF Gene. NCI Thesaurus. Code C94663.

This gene is involved in both the transport of iron and proteolysis. 